\title{
Cholestatic Syndromes in Infancy: Diagnostic Value of Serum Bile Acid Pattern and Cholestyramine Administration
}

\author{
Norman B. Javiti ${ }^{[22]}$, Kevin P. Morrissey, Elliot Siegel, Henry Goldberg, \\ Lawrenae M. Gartner, Melvin Hollander, and Engeline KoK \\ Departments of Medicine, Surgery and Pediatrics, Cornell University Medical College-New York Hospital, and the \\ Departments of Pediatrics, Albert Einstein College of Medicine and Fordham Hospital, \\ New York, New York, USA
}

\begin{abstract}
Extract
Changes in serum bile acid concentrations, before and after cholestyramine therapy, in a group of seven infants with extrahepatic biliary atresia and other cholestatic syndromes were measured with gas-liquid chromatography. Table I lists pertinent clinical and laboratory data and documents that all had consistently marked elevations of serum bile acid levels ranging from 48 to $444 \mu \mathrm{g} / \mathrm{ml}$. Four infants with biliary atresia had predominantly chenodeoxycholate in plasma. Administration of cholestryamine caused a reduction in serum bile acids in some infants and a slight increase in the cholate to chenodeoxycholate ratio from less than 1 to a maximum of 1.3 . Three children with intrahepatic cholestatic syndromes had predominantly cholic acid in plasma. Cholestyramine caused a reduction in total serum bile acids with an increase in the cholate to chenodeoxycholate ratio from 3.5 to 13 . The rationale for the use of cholestyramine is based on its capacity to bind bile salts in the intestines.
\end{abstract}

\section{Speculation}

Analysis of serum bile acid pattern in infants with cholestatic syndromes before and after cholestyramine administration may identify infants with intrahepatic disease and thus avoid surgical exploration.

\section{Introduction}

The development of accurate and relatively simple methods for the analysis of bile acids in serum has led to studies seeking to relate qualitative and quantitative changes in serum bile acid patterns to specific diseases of the liver and biliary tree. Although the increased proportion of chenodeoxycholate in cirrhosis has been well documented [3], the study of Sandberg [12] of normal infants and those with liver disease indicates that serum bile acid determinations are of limited usefulness in differential diagnosis.

The ability to distinguish reliably between extrahepatic biliary atresia and other cholestatic syndromes remains an unsolved clinical problem. Although the excretion of bile acids from the liver into the intestines is reduced in cholestasis [11], it might be expected that there is less impairment in comparison to atresia. Based on this assumption, we have compared the changes in serum acid levels, before and after chole- 
Table $I$. Cholestatic syndromes in infancy

\begin{tabular}{|c|c|c|c|c|c|c|c|c|}
\hline \multirow[b]{2}{*}{ Patient } & \multicolumn{2}{|c|}{ Entry into study } & \multirow[b]{2}{*}{ Sex } & \multirow[b]{2}{*}{$\begin{array}{l}\text { Bilirubin } \mathrm{D} / \mathrm{T} \\
\mathrm{mg} / 100 \mathrm{ml}\end{array}$} & \multirow{2}{*}{$\begin{array}{l}5^{\prime} \text {-Nucle- } \\
\text { otidase, } \\
\text { IU }<15^{1}\end{array}$} & \multicolumn{3}{|c|}{ Serum bile acid, $\mu \mathrm{g} / \mathrm{m}^{2}$} \\
\hline & Date & $\begin{array}{l}\text { Age, } \\
\text { mo }\end{array}$ & & & & $\begin{array}{l}\text { Cheno- } \\
\text { deoxy- } \\
\text { cholic }\end{array}$ & Cholic & Total \\
\hline \multicolumn{9}{|c|}{ Extrahepatic biliary atresia } \\
\hline$J J$ & $5 / 17 / 71$ & 10 & $\mathrm{M}$ & $5.4 / 11.1$ & 34 & 43 & 5 & 48 \\
\hline$V C$ & $12 / 13 / 71$ & 1 & $\mathrm{~F}$ & $3.2 / 5.8$ & 126 & 123 & 21 & 144 \\
\hline$M P$ & $2 / 3 / 72$ & 0.7 & $\mathrm{M}$ & $7.2 / 10.4$ & 252 & 126 & 23 & 149 \\
\hline$E T$ & $1 / 3 / 72$ & 7 & M & $11.0 / 13.5$ & 72 & 152 & 72 & 224 \\
\hline \multicolumn{9}{|c|}{ Other cholestatic syndromes } \\
\hline$P L$ & $12 / 6 / 71$ & 21 & $M$ & $1.0 / 1.5$ & 141 & 9 & 41 & 50 \\
\hline$K M$ & $11 / 30 / 70$ & 7 & $\mathrm{~F}$ & $11.2 / 21.1$ & 134 & 36 & 182 & 218 \\
\hline$J C$ & $4 / 18 / 71$ & 27 & M & $9.0 / 12$ & 549 & 94 & 350 & 444 \\
\hline
\end{tabular}

International units, normal $<15$ IU.

${ }^{2}$ Normal $=1-2 \mu \mathrm{g} / \mathrm{ml}$.

styramine therapy, in a group of infants with extrahepatic biliary atresia and other cholestatic syndromes.

\section{Materials and Methods}

Seven children are under study, some for as long as 2 years. Five of the children have been followed since birth and two entered the program at 2 years of age. None of the children were positive for hepatitis $\mathrm{B}$ virus, cytomegalo virus, or toxoplasmosis. $\alpha$-1-Antitrypsin levels were normal. There was no evidence for galactosemia or tyrosinemia. All children underwent liver biopsy and six of the seven children had an exploratory laparotomy, verifying the diagnosis.

Gas-liquid chromatographic analysis of serum bile acids was done using the method previously reported [2] with minor modifications. Sample size was reduced from 5 to $0.5 \mathrm{ml}$ serum. The internal standard was changed from $3 \alpha, 6 \alpha$-dihydroxy- $5-\beta$-cholanoate to $3 \alpha$,$7 \alpha, 12$-keto-5- $\beta$-cholanoate [18]. Acetate rather than trifluoroacetate derivatives were prepared because they can be stored for long periods of time without deterio-

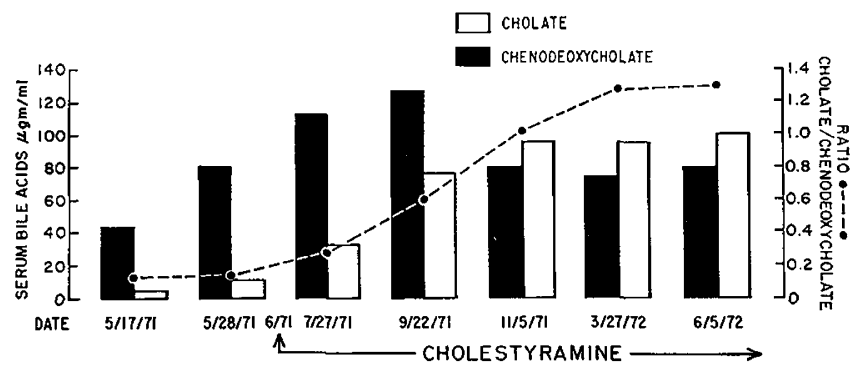

Fig. 1. Effect of cholestyramine on serum bile acid pattern in extrahepatic atresia. Patient JJ: Administration of cholestyramine, $4 \mathrm{~g} / 24 \mathrm{hr}$ for 9 months caused little reduction in total serum bile acids and only a small shift in the cholate to chenodeoxycholate ratio (from 0.1 to 1.3 ). ration. Duplicate analyses of serum were done periodically and on these occasions the two values agree within $10 \%$.

Other analytical studies were done either in the routine clinical laboratories of the various hospitals or by investigators who have been doing special studies as part of their research program [19].

\section{Resulls}

Table I lists the seven children studied, all of whom presented a similar clinical picture in the neonatal period. The date and age of each child at the time of entry into the study corresponds to the serum bilirubin determination as well as to the initial serum bile acid (SBA) analysis. 5'-Nucleotidase determinationś were consistently elevated in all children and wide fluctuations were observed, which appear unrelated to cholestyramine therapy. All of the children displayed a predominantly conjugated hyperbilirubinemia during the neonatal period which fell to levels of less than 2 $\mathrm{mg} / 100 \mathrm{ml}$ in one child before entry into the study. All had persistent elevations of bile acid levels in serum.

Four patients $(J J, V C, M P$, and $E T)$ had predominantly chenodeoxycholate in plasma. This unexpected SBA pattern was initially observed in $J J$ who had been explored for jaundice at age 3 months and found to have extrahepatic biliary atresia. The initial SBA analysis at age 10 months showed $89 \%$ of the elevation to be in the chenodeoxycholate fraction. The infant was started on treatment with cholestyramine, $4 \mathrm{~g} / 24 \mathrm{hr}$, at age 11 months and subsequent SBA determinations with respect to onset, duration, and dosage of cholestyramine therapy are given in Figure 1 . No fall in the total or component serum bile acid concentrations oc- 
curred, despite 9 months uninterrupted therapy. However, there has been a slow and gradual rise in the proportion of cholate from $11 \%$ to $56 \%$ of the total SBA over this period.

Subsequently, three additional neonates $(V C, M P$, and $E T$ ) with extrahepatic biliary atresia later confirmed by laparotomy, were found to display similar initial serum bile acid patterns and responses to cholestyramine (Table II). The predominant bile acid was chenodeoxycholic acid. With short courses of cholestyramine (8-12 g/24 hr for 15-30 days), there was only a slight increase in the proportion of cholate to chenodeoxycholate, and some decrease of the total SBA in two of the three children (MP and ET). Fluid obtained from a dilated hilar duct proximal to the atretic segment in patient $V C$ was found to contain chenodeoxycholate $(298 \mu \mathrm{g} / \mathrm{ml})$ but no cholate.

In three children $(P L, K M$, and $J C)$ the initial serum bile acid pattern displayed predominantly cholic acid
(Table I). Patient $K M$ was explored at age 3 months. Patent bile ducts were found and $0.3 \mathrm{ml}$ bile was aspirated from the gallbladder and analyzed. The total hepatic bile acid concentration was $107 \mu \mathrm{g} / \mathrm{ml}$, of which $69 \%$ was cholic acid and $31 \%$ was chenodeoxycholic acid. The initial SBA determination at age 7 months revealed a total SBA of $218 \mu \mathrm{g} / \mathrm{ml}$ (Table I) of which $84 \%$ was cholic acid and $26 \%$ was chenodeoxycholic acid. Total SBA values fluctuated but did not begin to consistently fall until after cholestyramine, 12 $\mathrm{g} / 24 \mathrm{hr}$, was started at age 10 months. During the initial treatment period, the ratio of cholate to chenodeoxycholate rose from 4 to 10 (Table III), followed by a gradual, sustained reduction in the total SBA. Concomitantly, pruritis, which had been severe prior to cholestyramine therapy, disappeared, and the total bilirubin fell to $2 \mathrm{mg} / 100 \mathrm{ml}$.

Patient $P L$ had been explored at age 2 months and diagnosed as having extrahepatic biliary atresia. He

Table II. Effect of cholestyramine on serum bile acid patterns in extrahepatic biliary atresia

\begin{tabular}{|c|c|c|c|c|c|c|c|}
\hline \multirow[b]{2}{*}{ Patient } & \multirow[b]{2}{*}{ Date } & \multicolumn{2}{|c|}{ Cholestyramine therapy } & \multicolumn{3}{|c|}{ Serum bile salt, $\mu \mathrm{g} / \mathrm{ml}$} & \multirow[b]{2}{*}{$\mathrm{CH} / \mathrm{C}^{1}$} \\
\hline & & $\begin{array}{c}\text { Dose } \\
\mathrm{g}\end{array}$ & $\begin{array}{l}\text { Duration, } \\
\text { days }\end{array}$ & $\begin{array}{l}\text { Chenodeoxy- } \\
\text { cholic acid }\end{array}$ & $\begin{array}{l}\text { Cholic } \\
\text { acid }\end{array}$ & Total & \\
\hline \multirow[t]{3}{*}{$J J$} & $5 / 28 / 71$ & Pretreatment & & 80 & 11 & 91 & 0.14 \\
\hline & $7 / 27 / 71$ & 4 & 60 & 113 & 33 & 146 & 0.29 \\
\hline & $6 / 5 / 72$ & 4 & 373 & 80 & 100 & 180 & 1.25 \\
\hline \multirow[t]{3}{*}{$V C$} & $12 / 13 / 71$ & Pretreatment & & 123 & 21 & 144 & 0.16 \\
\hline & $1 / 3 / 72$ & 8 & 3 & 128 & 19 & 147 & 0.15 \\
\hline & $1 / 18 / 72$ & 8 & 18 & 141 & 4 & 145 & 0.03 \\
\hline \multirow[t]{3}{*}{$M P$} & $2 / 3 / 72$ & Pretreatment & & 126 & 23 & 149 & 0.18 \\
\hline & $2 / 24 / 72$ & 4 & 13 & 47 & 18 & 65 & 0.37 \\
\hline & $3 / 31 / 72$ & 8 & 35 & 35 & 19 & 54 & 0.54 \\
\hline \multirow[t]{2}{*}{$E T$} & $1 / 3 / 72$ & Pretreatment & & 152 & 72 & 224 & 0.47 \\
\hline & $1 / 19 / 72$ & 12 & 16 & 48 & 28 & 76 & 0.56 \\
\hline
\end{tabular}

${ }^{1} \mathrm{CH} / \mathrm{C}$ : Ratio of cholic to chenodeoxycholic acid.

Table III. Effect of cholestyramine on serum bile acid patterns in cholestatic syndromes with patent bile ducts

\begin{tabular}{|c|c|c|c|c|c|c|c|}
\hline \multirow[b]{2}{*}{ Patient } & \multirow[b]{2}{*}{ Date } & \multicolumn{2}{|c|}{ Cholestyramine therapy } & \multicolumn{3}{|c|}{ Serum bile salt, $\mu \mathrm{g} / \mathrm{ml}$} & \multirow[b]{2}{*}{$\mathrm{CH} / \mathrm{C}^{1}$} \\
\hline & & $\begin{array}{c}\text { Dose, } \\
\mathrm{g}\end{array}$ & $\begin{array}{c}\text { Duration, } \\
\text { days }\end{array}$ & $\begin{array}{l}\text { Chenodeoxy- } \\
\text { cholic acid }\end{array}$ & $\begin{array}{l}\text { Cholic } \\
\text { acid }\end{array}$ & Total & \\
\hline \multirow[t]{3}{*}{$P L$} & $12 / 6 / 71$ & Pretreatment & & 9 & 41 & 50 & 4.6 \\
\hline & $3 / 9 / 72$ & 6 & 47 & 6 & 50 & 56 & 8.1 \\
\hline & $4 / 14 / 72$ & 6 & 82 & 0.7 & 8.7 & 9.4 & 12.4 \\
\hline \multirow[t]{3}{*}{$K M$} & $2 / 2 / 71$ & Pretreatment & & 23 & 114 & 137 & 4.9 \\
\hline & $7 / 21 / 72$ & 4 & 15 & 7 & 43 & 50 & 6.1 \\
\hline & $8 / 10 / 72$ & 12 & 20 & 10 & 104 & 114 & 10.6 \\
\hline \multirow[t]{3}{*}{$J C$} & $1 / 18 / 72$ & Pretreatment & & 105 & 383 & 488 & 3.7 \\
\hline & $2 / 4 / 72$ & 12 & 16 & 17 & 66 & 83 & 3.8 \\
\hline & $3 / 14 / 72$ & 12 & 38 & 18 & 63 & 81 & 3.5 \\
\hline
\end{tabular}

${ }^{1} \mathrm{GH} / \mathrm{G}$ : Ratio of cholic to chenodeoxycholic acid. 


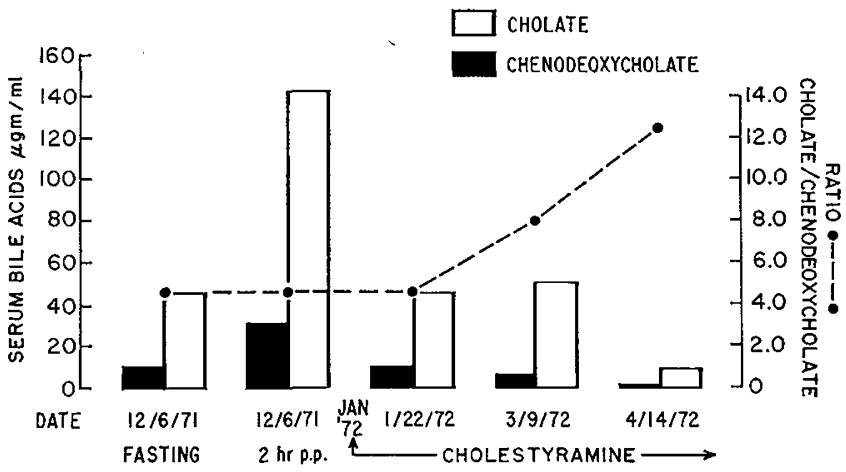

Fig. 2. Effect of cholestyramine on serum bile acid pattern in neonatal cholestatic syndrome. Patient PL: Administration of cholestyramine $12 \mathrm{~g} / 24 \mathrm{hr}$ for 3 months caused a fall in the total serum bile acid level and a marked shift in the cholate to chenodeoxycholate ratio (from 4.6 to 12.4).

came to our attention at age 21 months, by which time jaundice, but not pruritis, had disappeared. Because of fluctuations in the serum bile acid levels, we began to study systematically the fasting and 2-hr postprandial levels (Fig. 2, Table III) and found that much of the fluctuation could be attributed to elevations after meals.

The following year, the serum cholesterol rose to $512 \mathrm{mg} / 100 \mathrm{ml}$ and cholestyramine, $12 \mathrm{~g} / 24 \mathrm{hr}$, treatment was started. Total bile acid levels both pre- and postprandial fell with a rise in the cholate-chenodeoxycholate level in serum from 4.0 to 12.0 (Fig. 2). The serum cholesterol fell promptly to $230 \mathrm{mg} / 100 \mathrm{ml}$.

Patient JC was jaundiced at birth. Clinical and laboratory data, including liver biopsies at age 11 days and at age 2 years were interpreted as consistent with a cholestatic syndrome with no strong evidence for a diagnosis of extrahepatic biliary atresia. Exploratory laparotomy has not been done. At the time of entry into the study at age 27 months, the child was still jaundiced and had severe pruritus and hypercholesterolemia (>1500 mg/100 ml) with xanthoma. The total serum bile acid was $488 \mu \mathrm{g} / \mathrm{ml}, 79 \%$ consisting of cholic acid. Cholestyramine therapy (Table III) was followed by a prompt fall in serum cholesterol to 400 $\mathrm{mg} / 100 \mathrm{ml}$ and bile acid levels to $83 \mu \mathrm{g} / \mathrm{ml}$.

\section{Discussion}

Cholestatic syndromes presenting at any age are a difficult diagnostic and therapeutic problem. In the neonatal period, a major problem is the distinction between atresia of the extrahepatic bile ducts, and intrahepatic disturbances in bile formation. Among the intrahe- patic disturbances that have been reported to occur are both anatomic reduction in the size of the bile secretory apparatus [1] and metabolic abnormalities in bile acid synthesis [10]. Because of the increased mortality rate associated with surgery [8] and the beneficial effect that can occur with cholestyramine therapy [13], we undertook a study of the diagnostic and therapeutic usefulness of this agent.

The rationale for the use of cholestyramine as a diagnostic agent to distinguish between complete and incomplete interruption in bile flow is based on its capacity to bind bile salts in the intestines. No other mechanism of action for this nonabsorbable anion exchange resin has been established. As a consequence of binding there is an increase in fecal bile acid excretion and an increase in hepatic synthesis of bile acid.

Although cholestyramine can have a variety of effects on bowel motility which can cause problems [4], no untoward effects occurred during the course of this study.

Depending on the relative rates of hepatic synthesis and fecal excretion of bile acids, pool size may remain the same or decrease. In addition to the effect of cholestyramine on bile acid turnover, it is known to increase the proportion of glycocholate present in the bile salt pool. This occurs because the resin is known to bind relatively more chenodeoxycholate compared with cholate $[5,7]$ and conjugation with glycine in the liver becomes proportionally greater when there is an increase in fecal excretion [6]. Thus, the effects of cholestyramine on bile acid metabolism are known and are predictable.

The administration of cholestyramine to infants with bile acid retention as part of a cholestatic syndrome can be expected to have an effect proportional to the amount of bile acid bound in the intestine. The sources of intestinal bile acids are primarily those excreted via the common bile duct by the liver, and to a minor extent, that derived from the turnover of intestinal mucosal cells that may contain bile salts absorbed from the extracellular fluid, when plasma levels are very high. Since the predominant source is via hepatic excretion, the effect of cholestyramine can be expected to be related for the most part to the amount of bile acid excreted via the bile ducts.

The three patients with a predominantly cholate pattern had a marked response to cholestyramine. Two of the babies $(P L$ and $J C)$ entered the study at about 2 years of age and had marked hypercholesterolemia. The serum cholesterol level fell more rapidly than the 
total serum bile acid level. During the course of these studies it became apparent that the serum bile acids fluctuate greatly during the day, presumably due to emptying of the gallbladder containing some bile salts. This view is supported by other studies in the adult [9] showing that individuals with elevated fasting levels of serum bile salts have three- to fourfold increases after eating. Consistent fasting samples are harder to obtain in babies on short interval feeding schedules, and probably also in young children.

For these reasons, we have placed more emphasis on following changes in the ratio of cholate to chenodeoxycholate as evidence of significant bile acid binding by cholestyramine. A cholate to chenodeoxycholate ratio which is initially greater than, or which more rapidly shifts to levels greater than 2 appears characteristic of the patients with a cholestatic syndrome and patent bile ducts. In patients seen later in life with hypercholesterolemia and high levels of cholate, a shift may be delayed in appearance. Although chenodeoxycholate is preferentially bound by the resin, it is present in relatively small amounts and, therefore, statistically, the resin will come in contact with much more cholate.

The four infants with predominently chenodeoxycholate in the serum had much less of a response to cholestyramine. In three of the infants, the total serum bile acid level did not fall and only a slight increase in the proportion of cholate occurred after prolonged treatment. These relatively small changes are consistent with the view that small amounts of bile acids entering the intestinal lumen via the turnover of mucosal cells are bound by the resin.

One of the children $(J J)$ with a poor response to cholestyramine was known to have biliary atresia before treatment. The diagnosis of biliary atresia was strongly suspected preoperatively in the other three infants, based on the initial serum bile acid pattern and response to cholestyramine.

The predominance of chenodeoxycholate in babies subsequently found to have atresia was not anticipated. The studies by Sandberg [12] of serum bile acids in normal infants and in those with liver disease did not distinguish patterns particularly diagnostic of atresia or other specific diseases. Our experience thus far indicates that the appearance within the first few months of life of a predominantly chenodeoxycholate pattern is suggestive of extrahepatic atresia. Perhaps the mechanism for this occurrence is related to the more rapid development of cirrhosis in infants with complete atresia. The predominance of chenodeoxy- cholate in cirrhosis in the adult has previously been noted $[3,16]$ and has been found to be attributable to a marked reduction in the cholate pool [17]. In the light of present knowledge it seems most reasonable to consider the predominant chenodeoxycholate pattern as evidence of the cirrhosis that will occur in these infants [15]. One cannot exclude however, the speculative possibility that this pattern may have existed in fetal life and in some manner is related to the excretory defect.

Although it seems reasonable to attempt to distinguish extrahepatic atresia from other cholestatic syndromes, this latter group may represent a wide variety of undefined diseases affecting the liver. Thus, some may occur because of a paucity of intrahepatic bile ducts [13] and others because of the synthesis of excessive amounts of monohydroxy bile acids [10], which are known to cause cholestasis [8]. Some infants apparently respond rapidly to intramuscular phenobarbital [14] and others have virtually no bile acid in their bile at the time of surgery [11].

Of the seven children reported here, two appear to resemble those discussed previously [1] with marked hypercholesterolemia that responds rapidly to cholestyramine. Our findings in the other infants thus far do not permit any further classification. One baby, $K M$, failed to respond to phenobarbital therapy on two occasions, before cholestyramine therapy began. Thus, it seems likely that neonatal cholestatic syndromes represent a heterogeneous group of disorders that require long term study to fully characterize their course.

\section{Summary}

Seven children with persistent cholestatic syndromes have been followed for as long as 2 years. Serum bile acid levels were determined periodically before, during, and after treatment with cholestyramine. The initial serum bile acid pattern in four infants with extrahepatic biliary atresia showed predominantly chenodeoxycholic acid. Cholestyramine administration had relatively little effect on the total serum bile acid level and the ratio of cholate to chenodeoxycholate. Three infants with intrahepatic cholestatic syndromes had predominantly cholic acid in the serum and cholestyramine administration caused a reduction in the total level. The initial serum bile acid patterns and response to cholestyramine appears to distinguish between extrahepatic biliary atresia and other cholestatic syndromes. 


\section{References and Notes}

1. Ahrens, E. H., Jr., Harris, R. G., and Macmahon, H. E.: Atresia of the intrahepatic bile ducts. Pediatrics, 8: 396 (1951).

2. Ali, S. S., ANd Javitr, N. B.: Quantitative estimation of bile salts in serum. Can. J. Biochem., 48: 1054 (1970).

3. Carey, J. B., JR.: The serum trihydroxy-dihydroxy bile acid ratio in liver and biliary tract disease. J. Clin. Invest., 37: 1494 (1958).

4. Cohen, B., Winslow, P. R., And Boley, S. J.: Intestinal obstruction associated with cholestyramine therapy. New Engl. Med. J., 280: 1185 (1969).

5. Cook, D. A., Hagerman, L. M., and Schneider, D. L.: Preferential retention of taurine-conjugated bile salts by cholestyramine in the rat ileum. Proc. Soc. Exp. Biol. Med., 139: 70 (1972).

6. Garbutt, J. T., LAcK, L., ANd Tyor, M. P.: The enterohepatic circulation of bile salts in gastrointestinal disorders. Amer. J. Med., 51: 327 (1971).

7. Hagerman, L. M., Cook, D. A., ANd Schneider, D. L.: Effect of cholestyramine particle size on in vitro binding of conjugated bile salts. Proc. Soc. Exp. Biol. Med., 139: 248 (1972).

8. Javitr, N. B., ANd Emerman, S.: Effect of sodium taurocholate on bile flow and bile acid secretion. J. Clin. Invest., 47: 1002 (1968).

9. Kaplowitz, N., KoK, E., AND JavrtT, N.: Postprandial serum bile acid: a sensitive test of liver function (Abstract). Gastroenterology, 62: 768 (1972).

10. Makino, I., Sjovall, J., Norman, A., And Strendvik, B.: Excretion of $3 \beta$-hydroxy-5-cholenoic and $3 \alpha$-hydroxy- $5 \alpha$-cholanoic acids in urine of infants with biliary atresia. Fed. Eur. Biochem. Soc. Lett., 15: 161 (1971).

11. Norman, A., Strandvik, B., and Zetterstrom, R.: Bile acid excretion and malabsorption in intrahepatic cholestasis of infancy ("neonatal hepatitis"). Acta, Paediat. Scand., 58: 59 (1969).
12. SANDBERG, D. H.: Bile acid concentrations in serum during infancy and childhood. Paediat. Res., 4: 262 (1970).

13. Sharr, H. L., Carex, J. B., JR., White, J. G., and Krivit, W.: Cholestyramine therapy in patients with a paucity of intrahepatic bile ducts. J. Pediat., 71: 723 (1967).

14. Stiehl, A., Thaler, M., and Admirand, W. H.: The effects of phenobarbital on bile salts and bilirubin in patients with intrahepatic cholestasis. New Engl. J. Med., 286: 858 (1972).

15. Thaler, M. M., and Gellys, S. S.: Studies in neonatal hepatitis and biliary atresia. II. The effect of diagnostic laparotomy on long-term prognosis of neonatal hepatitis. Amer. J. Dis. Child., 116: 262 (1968).

16. Vlahcevic, Z. R., Buhac, I., and Farrer, J. T.: Bile acid metabolism in patients with cirrhosis. I. Kinetic aspects of cholic acid metabolism. Gastroenterology, 60: 491 (1971).

17. Vlahcevic, Z. R., Juttijudata, P., Bell, C. C., JR., and Swell, L.: Bile acid metabolism in patients with cirrhosis. II. Cholic and chenodeoxycholic acid metabolism. Gastroenterology, 62: 1174 (1972).

18. Available from Mann Research Laboratories, Inc., New York, N. Y.

19. We thank Dr. George Falk of the Pulmonary Division of the New York Hospital for the $\alpha$-1-antitrypsin determination.

20. This study was performed within the spirit of the Declaration of Helsinki.

21. This research was supported by Training Grant no. AM 05430 and Research Grant no. AM 13094, National Institutes of Health.

22. Requests for reprints should be addressed to: Norman B. JAvirx, M.D., Chief, Gastroenterology Division, The New York Hospital-Cornell Medical College, 1300 York Avenue, New York, New York 10021 (USA).

23. Accepted for publication November 27, 1972.

24. Career Development Awardee, National Institute of Child Health and Human Development. 


\section{Appendix}

Reports of Liver Biopsy of Neonatal Cholestatic Syndromes

\begin{tabular}{|c|c|c|}
\hline Patient & Age at biopsy & Report \\
\hline \multirow[t]{2}{*}{$J J(\mathbf{a})$} & 11 weeks & $\begin{array}{l}\text { The capsule is unremarkable. The general architecture is well preserved. There is severe } \\
\text { intracanalicular and intraductal bile stasis. No inflammatory reaction or necrosis is seen. } \\
\text { The portal triads exhibit mild fibrosis which extends in thin bands between the surrounding } \\
\text { lobules. There is a reduplication of bile ducts within portal triads. Focal areas of necrosis } \\
\text { and scattered multinucleated hepatocytes are present. }\end{array}$ \\
\hline & & $\begin{array}{l}\text { Diagnosis: Wedge biopsy of liver with severe bile stasis and periportal fibrosis consistent with } \\
\text { clinical extrahepatic biliary obstruction. }\end{array}$ \\
\hline$V C(\mathrm{~b})$ & 5 weeks & $\begin{array}{l}\text { Increased connective tissue in the portal zones. Also increased proliferation of bile ducts and } \\
\text { mononuclear inflammatory cells. Many ducts show precipitated bile and many liver cells } \\
\text { exhibit bile retention. Biopsy suggestive of extrahepatic bile duct atresia and biliary cirrho- } \\
\text { sis. Iron stains show minimal Prussian blue stain. }\end{array}$ \\
\hline$M P(\mathrm{c})$ & 17 weeks & $\begin{array}{l}\text { Portal tracts are expanded and show marked fibrosis with some bridging, edema, and infiltra- } \\
\text { tion with polymorphs. There is marked cholestasis with bile plugging, particularly evident } \\
\text { in portal areas. Bile duct proliferation is seen. Ductules are small and distorted with irregular } \\
\text { epithelium. There is no evidence of hepatitis. Appearances are those of large duct biliary } \\
\text { obstruction and are compatible with biliary atresia. }\end{array}$ \\
\hline$E T(b)$ & 7 weeks & $\begin{array}{l}\text { Changes of cholestasis and cirrhosis, with increased periportal fibrosis, proliferation of bile } \\
\text { ducts, and inflammatory infiltrate with eosinophils. Occasional giant cells as well as cho- } \\
\text { lestasis in canaliculi and liver cells. Consistent with extrahepatic biliary atresia and biliary } \\
\text { cirrhosis. }\end{array}$ \\
\hline$P L(\mathrm{c})$ & 10 weeks & Consistent with biliary atresia and massive bile stasis. \\
\hline$K M(\mathrm{c})$ & 13 weeks & $\begin{array}{l}\text { Marked bile stasis and moderate increase in periportal connective tissue with bile duct } \\
\text { proliferation. Consistent with extrahepatic bile duct obstruction. }\end{array}$ \\
\hline
\end{tabular}

${ }^{1}$ From the Department of Pathology of the contributing hospitals: (a) Bellevue Hospital, New York, N.Y.; (b) Fordham Hospital, Bronx, N.Y.; (c) New York Hospital, New York, N.Y. 